\title{
Knowledge sharing via social media in software development: a systematic literature review
}

Sarka, Peter Bo; Ipsen, Christine

Published in:

Knowledge Management Research \& Practice

Link to article, DOI:

10.1057/s41275-017-0075-5

Publication date:

2017

Document Version

Peer reviewed version

Link back to DTU Orbit

Citation (APA):

Sarka, P. B., \& Ipsen, C. (2017). Knowledge sharing via social media in software development: a systematic literature review. Knowledge Management Research \& Practice, 15(4), 594-609. https://doi.org/10.1057/s41275017-0075-5

\section{General rights}

Copyright and moral rights for the publications made accessible in the public portal are retained by the authors and/or other copyright owners and it is a condition of accessing publications that users recognise and abide by the legal requirements associated with these rights.

- Users may download and print one copy of any publication from the public portal for the purpose of private study or research.

- You may not further distribute the material or use it for any profit-making activity or commercial gain

- You may freely distribute the URL identifying the publication in the public portal

If you believe that this document breaches copyright please contact us providing details, and we will remove access to the work immediately and investigate your claim 


\title{
Knowledge sharing via social media in software development: A systematic literature review
}

\begin{abstract}
Effective knowledge exchange among software developers is crucial for the competitive performance of their organizations. Today, the constant pressure on businesses to continually innovate and the increasing capability of information technologies to facilitate broader and more distributed communication are driving organizations to leverage social media tools to improve performance. These tools, which have changed the way we share knowledge, enable people to connect, communicate, and collaborate. Research on knowledge sharing via social media is still in its early phases, with a comprehensive overview of the literature yet to be completed. Thus, using a systematic literature review approach, this study aims to map the current literature on the topic in relation to software development. Furthermore, this study highlights the findings of former research and identifies gaps in the literature. The study offers several insights for researchers and practitioners and proposes a future research agenda to strengthen knowledge in the field.
\end{abstract}

Keywords: Systematic literature review, knowledge sharing, social media, software development, future research agenda. 


\section{Introduction}

Social media is radically changing the technological landscape, affecting people's interactions and thus society. Communication has become fundamentally different from just two decades ago. In the early 2000s, Prensky promoted the notion that regardless of whether organizations advocate using social media, their employees, especially those among the younger generations, would increasingly adopt competences and attitudes towards sharing (Prensky, 2001). The extensive use of social media for knowledge sharing and social networking would characterize the so-called "digital natives" (Prensky, 2001; Selwyn, 2009; Deal et al, 2010; Kaplan \& Haenlein, 2010), who have grown up in a sharing culture influenced by the extensive use of social media. Thus, when entering organizations, this demographic expects to meet demands and respond to experiences in a manner similar to everyday life (Carswell (2007) in Levy, 2009). Social media tools have infiltrated our society, however, in such a way that their usage can no longer be attributed solely to the younger generations (Perrin, 2015). Hence, it is necessary to examine social media usage and its accompanying challenges within current organizational settings.

According to McAfee (2010), we are currently witnessing the infiltration of many social media tools into companies (McAfee, 2010). Today, companies and employees recognize the potential of social media as an internal communications tool, and consequently, the use of social media has been rising rapidly (Black et al, 2010; Keitt et al, 2011; Sarka et al, 2014). Social media has been acknowledged as providing complementary features to traditional communication tools, such as email, phone, and video conferencing systems, which has caused it to be increasingly used for capturing and sharing knowledge (Ferro et al, 2012). These points reflect the general recognition of the potential of social media in organizations.

To accomplish work more effectively and efficiently (Fisher \& Fisher, 2001), companies often now globally distribute their organizational processes (Bertoni et al, 2012), which means that members of an organization must deal with both spatial (location) and temporal boundaries (different work hours) (Fisher \& Fisher, 2001; Cummings et al, 2009) when communicating via information technology (Bell \& Kozlowski, 2002; Grabowski \& Roberts, 2016). Kotlarsky and Oshri (2005) argue that organizational mechanisms that create social spaces between people are required in order to achieve successful collaboration, especially among globally distributed teams (Kotlarsky \& Oshri, 2005).Software development is a highly collaborative activity wherein communication and knowledge sharing are necessary to meet the needs of users and stakeholders. The need for supporting tools is particularly well recognized in the software development field, where jobs are conducted among different locations (Kraut \& Streeter, 1995; Espinosa et al, 2007). Knowledge sharing can be defined as providing or receiving knowledge, know-how or feedback concerning a given product or procedure (Hansen et al, 1999). Knowledge sharing provides people with an 
understanding of the knowledge and skills of others, and allows them to respond to situational demands given complex tasks potentially beyond their cognitive skill level (Szulanski, 2000). Knowledge sharing also includes the implicit and social coordination mechanism of knowledge (Faraj \& Sproull, 2000).

Given that knowledge sharing is a vital part of the everyday life of a software developer, knowledge sharing activities are highly important to implement so as to ensure speed, innovation, and effectiveness. It is integral for software development organizations to focus on the social creation and distribution of knowledge, as their knowledge workers are currently attempting to solve problems of a different magnitude than in prior decades (Bertoni et al, 2012). As the scope of organizational activities rapidly develops, software developers share and utilize a wider array of data, information, and knowledge than has previously been available in traditional organizational contexts. Along with the increasing globalization, technological innovation makes organizations more reliant on information communication technologies (ICT) (Bertoni et al, 2012).

Today's generation of developers frequently make use of social media to support their collaborative environment (Begel et al, 2010; Storey et al, 2010). Social media includes a broad and fast growing variety of tools, such as blogs, RSS, wikis, social networking platforms, instant messaging (IM), gaming, and more. According to Farkas (2007), social media refers to anything that meets two out of three following conditions: I) tools that allow people to communicate, collaborate, and build communities online, II) tools that can be syndicated, shared, reused, remixed, or facilitate syndication, and III) tools that let people learn easily from and capitalize on the behavior or knowledge of others (Farkas, 2007). Kaplan and Haenlein (2010) describe social media as a group of internet-based tools that build on the ideological and technological foundations of Web 2.0, and that allow for the creation and exchange of user generated content (Kaplan \& Haenlein, 2010). This paper apply these two definitions and the term "social media" is used broadly to denote a group of products and services that enable social interactions in the digital realm.

As part of individuals' daily tasks, social media can help to connect people to new knowledge and experiences rather than well-known and potentially redundant ones (Bertoni et al, 2012). In doing this, social media can help developers to more effortlessly and effectively develop the 'know what' (Ryle, 1984), 'know-how' (Ryle, 1984), and 'know-who' (Larsson, 2005) needed to achieve their objectives. Social media also presents unprecedented prospects for communication between employees by creating opportunities for instant cross-boundary and cross-functional communication, facilitating knowledge sharing that bridges time and space (Cummings et al, 2009). It also helps to establish relationships and knowledge repositories that were formerly unavailable to employees. Furthermore, different kinds of social media have different characteristics to offer. For example, wikis serve as platforms for idea exchange, discussion [HZZOZ], and 
general knowledge sharing [WW11], while IM is often used as a real-time glue between different communication and collaboration channels [DG11]. Moreover, social media raises awareness of and simplifies knowledge sharing through lightweight tools (Giuffrida \& Dittrich, 2013).

Social media has introduced a dramatic change to the software developer landscape and old assumptions are challenged (Storey et al, 2014). Today, software developers openly contribute to online knowledge creation and the recognition of social connectedness is gaining increasing attention (Storey et al, 2014). Social media is seen as an extremely important developer resource that provides updatable documentation and high quality answers as well as dialogue opportunities (Treude et al, 2011). Having improved response time significantly compared to traditional communication methods (Mamykina 2011), social media is unavoidable for software developers. The outcome is a shift in work processes, and the wish to communicate face-to-face is challenged by many-to-many communication (Storey et al, 2014). However, whereas some perceives social media to provide a larger user community than accessible by traditional communication tools (Squire 2015), concerns are also raised regarding information overload and quality assessment (Squire 2015, Storey et al, 2014). Thus, social media is creating novel preconditions and expectations for software developers to adhere to.

The rapidly growing interest in social media across various research fields necessitates an overview of the current research on the topic. However, research on knowledge sharing via social media related to software development is still in its early stages and initial engagement with the literature in this field revealed it to be confusing and scattered. There are many disparate conceptualizations of social media (Richter et al, 2011), and the literature is often vague and dispersed (Gancho et al, 2013). Despite the field's lack of an overview (Storey et al, 2010), a growing interest in social media and their potential offerings was evident in the literature. The literature showed identifications that the field could be facing rapidly gamechanging development and many studies popped up in different and scattered settings. As the introduction of social media to the general discussion on computer supported cooperative work (CSCW) is somehow still novel and emerging, the field has not reach a mature state with common references and a general valid background knowledge database. Therefore, this paper conducts a systematic literature review (SLR) of existing research literature on knowledge sharing via social media in relation to software development. This review can be used to identify possible gaps in the literature so as to inform future research agendas and generally improve research within the field.

\section{Method}

Given, that software development is one of the most mature and advanced fields in terms of social media usage for work purposes, it offers a comprehensive foundation for the analysis and comparison of novel 
technologies. This SLR is part of a research project that is exploring how social media is used to share knowledge within the field. Corresponding with the main research topic of the project at large, the primary inquiry of this review relates to how social media can support knowledge sharing activities.

This review follows a five-step approach (Denyer \& Tranfield, 2009). This approach allows for comprehensive coverage of the literature and ensures auditability and repeatability for future searches. Figure I illustrates the five steps, which the following sections detail.

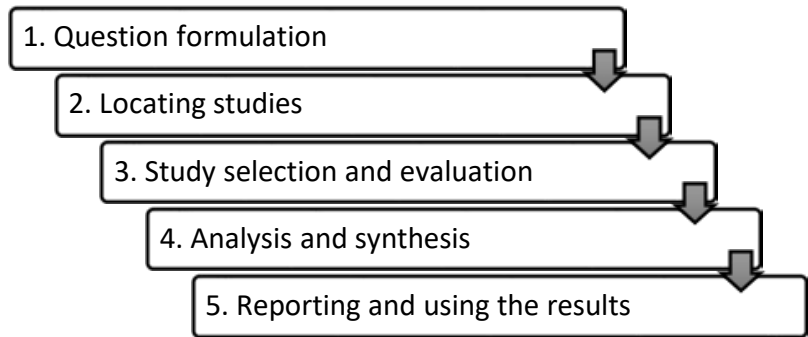

Figure I - Overview of the five-step systematic literature review approach

\section{Question formulation}

In the first step of this review's approach, the research questions to guide the review were formulated. A clear research question is critical to provide focus and direction to an SLR. The main research question was established via discussions between the authors and colleagues within the knowledge sharing field. The research question was formulated using the following CIMO logic (Denyer et al, 2008).

Context: Software development teams.

Interventions: The use of social media tools in software development projects.

Mechanisms: Knowledge sharing activities.

Outcomes: Usage of social media for knowledge sharing in software development.

This logic represents a comprehensive background to map the landscape of the social media literature within the scope of this paper.

\section{Research Questions}

To examine the current state of research on knowledge sharing via various social media tools, the following primary research question was formulated:

How does social media support knowledge sharing activities in the field of software development?

This question is supported by two sub-questions:

1. How are social media reported to be used for knowledge sharing activities by software developers? 
2. How is knowledge sharing via social media being researched?

\section{Locating studies}

This systematic review aims to locate, select, and appraise as much of the relevant research as possible related to the research question (Denyer \& Tranfield, 2009). This second step of the review's approach involves the creation of a comprehensive search string to ensure the identification of all relevant studies. Following this, relevant databases to conduct the search within will be identified.

\section{Search string}

An automatic search of electronic databases was conducted using a broad and comprehensive search string. The search string included a combination of three sets of keywords that related to social media, the subject, and the discipline. These three sets of keywords were used to construct a search string with the Boolean operators AND and OR.

\{Social Media\} AND $\{$ subject $\}$ AND $\{$ discipline $\}$

The final search query is shown in Table I. 


\begin{tabular}{|c|c|c|c|c|}
\hline Social media & & Subject & & Discipline \\
\hline "social media" OR & & "knowledge sharing" OR & & "software engineering" OR \\
\hline "social software" OR & & "knowledge transfer" OR & & "software development" OR \\
\hline "social technolog*" OR & & "knowledge distribution" OR & & "IT development" OR \\
\hline "social network*" OR & AND & "computer-mediated communication" OR & AND & "software quality" OR \\
\hline "web 2.0" OR & & "computer-mediated collaboration" OR & & "software testing" OR \\
\hline "social bookmark*" OR & & "computer supported co-operative work" & & "software architecture" OR \\
\hline "social tagging" OR & & & & "requirement engineering" OR \\
\hline "social platform*" OR & & & & "requirement specification" OR \\
\hline "social web tool*" OR & & & & "quality assurance" \\
\hline \multicolumn{5}{|l|}{ "social web" OR } \\
\hline \multicolumn{5}{|c|}{ "user generated media" OR } \\
\hline \multicolumn{5}{|c|}{ "user generated content" OR } \\
\hline \multicolumn{5}{|l|}{ "instant messaging" OR } \\
\hline \multicolumn{5}{|c|}{ "online discussion forum*" OR } \\
\hline \multicolumn{5}{|l|}{ “Q\&A" OR } \\
\hline \multicolumn{5}{|l|}{ wiki* OR } \\
\hline \multicolumn{5}{|l|}{ Facebook OR } \\
\hline \multicolumn{5}{|l|}{ Twitter OR } \\
\hline \multicolumn{5}{|l|}{ blog* OR } \\
\hline \multicolumn{5}{|l|}{ microblog* OR } \\
\hline \multicolumn{5}{|l|}{ SharePoint OR } \\
\hline Yammer & & & & \\
\hline
\end{tabular}

The above definition of the search terms ensured the identification of a list of studies that would be both broad enough to recall a sufficient quantity of references and precise enough, given increasing amounts of information, to eliminate unnecessary material (Duff, 1996).

\section{Databases}

The second key decision to make is to choose which search engines to use. First, pre-known databases were explored to identify if they contained publications within the field of study. Second, databases used in other review studies within the same field were identified. Third, an experienced reviewer who has conducted comprehensive acknowledged literature reviews (e.g. Heisig, 2009) within similar fields scrutinized the list of identified databases, and a final list of seven databases was agreed upon. Given that the context of the study is knowledge sharing via social media in the field of software development, these databases were identified to provide the best coverage of the field. In some cases, a certain study identified through Scopus were not identified through the direct database (e.g., Science Direct, EBSCO), despite the 
study being placed within this database. This enhances the rationale for choosing several different types of

databases for the search. The selected databases with identified studies were Scopus (2.381), Science Direct (317), Springer Link (18), Association of Computing Machinery (ACM) (717), EBSCO (29), Web of Science (237) and The Institute of Electrical and Electronics Engineers (IEEE) (536).

\section{Study selection and evaluation}

All identified studies were exported to the reference management software package Refworks (Refworks). First, the software was used to eliminate duplicates. Then, a screen based on the relevance of the title of the studies to the research questions identified papers relevant for a more in-depth review of the abstract, and subsequently, the full paper. Relevant studies were selected using explicit inclusion and exclusion criteria (Table II). 
Table II - Criteria for including and excluding identified studies

\begin{tabular}{|c|c|}
\hline Criteria & Rationale \\
\hline \multicolumn{2}{|l|}{ Inclusion criteria } \\
\hline $\begin{array}{l}\text { Papers in peer reviewed journals, conference } \\
\text { papers, working papers, workshop } \\
\text { proceedings, editorials and reviews }\end{array}$ & $\begin{array}{l}\text { The field of social media is experiencing increasing attention. However, } \\
\text { it is still an emerging field, and excluding works-in-progress such as } \\
\text { conference papers and working papers could leave out important } \\
\text { research. }\end{array}$ \\
\hline $\begin{array}{l}\text { Papers must have social media and knowledge } \\
\text { sharing as a main theme }\end{array}$ & $\begin{array}{l}\text { The focus of the research is to study knowledge sharing through social } \\
\text { media. }\end{array}$ \\
\hline $\begin{array}{l}\text { Papers must focus on software development or } \\
\text { related fields }\end{array}$ & $\begin{array}{l}\text { The aim of the research is to explore and map the current state of } \\
\text { studies on knowledge sharing via social media related to software } \\
\text { development. }\end{array}$ \\
\hline $\begin{array}{l}\text { Selection of papers will be open to any time } \\
\text { frame }\end{array}$ & $\begin{array}{l}\text { The field has developed significantly in recent years, but some parallels } \\
\text { can be drawn to earlier papers. }\end{array}$ \\
\hline $\begin{array}{l}\text { Theoretical papers, empirical papers, and } \\
\text { review papers, either qualitative or } \\
\text { quantitative }\end{array}$ & Different approaches have contributed to the field of study. \\
\hline \multicolumn{2}{|l|}{ Exclusion criteria } \\
\hline $\begin{array}{l}\text { Papers related to topics where the focus is not } \\
\text { on knowledge sharing and social media }\end{array}$ & $\begin{array}{l}\text { Many papers focus on other ways to share knowledge, but the focus in } \\
\text { this study is on knowledge sharing via social media. }\end{array}$ \\
\hline $\begin{array}{l}\text { Papers related to fields not comparable to } \\
\text { software engineering }\end{array}$ & Many papers focus on other fields (e.g., education and healthcare). \\
\hline $\begin{array}{l}\text { All studies in any other language than English } \\
\text { or Danish }\end{array}$ & $\begin{array}{l}\text { These languages are the ones that can be read by the review } \\
\text { researchers. }\end{array}$ \\
\hline
\end{tabular}

When identifying studies within the same body of research or the predecessors of another identified study, only the most complete or newest version was retained. The removal of duplicates, and subsequently, those studies on the first screen (based on the relevance of the title to the research question) resulted in the retention of 565 studies for a more in-depth review of the abstract. Selection was then carried out by first reviewing a study's abstract and afterwards reviewing the full papers that were selected based on their abstracts. A total of 459 studies were rejected predominantly due to a review of their abstracts, with some rejections based on a review of full papers, leaving a total of 106 studies remaining. 
Table III shows the selected databases and the corresponding number of identified objects based on the search string.

Table III - Databases and number of studies identified 8 March 2015

\begin{tabular}{lcccc}
\hline & & No. of & No. of & No. of \\
& & studies left & studies left & studies left \\
Databases & No. of & after & after & after \\
& studies & screening of & screening of & screening of \\
& & titles & abstracts & full papers \\
& & 210 & 36 & 24 \\
\hline Scopus & 2.381 & 13 & 0 & 0 \\
Science Direct & 317 & 1 & 0 & 0 \\
Springer Link & 18 & 178 & 76 & 37 \\
Association of Computing Machinery (ACM) & 717 & 5 & 2 & 2 \\
EBSCO & 29 & 55 & 14 & 14 \\
Web of Science & 237 & 103 & 29 & 29 \\
The Institute of Electrical and Electronics Engineers (IEEE) & 536 & 565 & 157 & 106 \\
\hline Total & 4.235 & & & 29 \\
\hline
\end{tabular}

\section{Analysis and synthesis}

A summary of the information contained in each paper was prepared in spreadsheet format organized in terms of descriptive, methodological, and thematic categories (Table IV). The descriptive and methodological analyses were more deductive in nature and focused on the categorization of the identified studies by year, journal, title, paper type, etc. A more inductive approach was taken for the thematic analysis, which analyzed and mapped the discussion in research studies of knowledge sharing via social media in the field of software development. The goal of this was to identify emerging constructs related to different social media tools for knowledge sharing, as well as to identify gaps in the literature and future research agendas. Two authors coded the data independently to ensure inter-coder reliability (Cho, 2008). Where views differed, issues of disagreement were discussed between the authors until resolved (Miles \& Huberman, 1994). 
Table IV - Categories used in extracting and analyzing data from the identified studies

\begin{tabular}{|c|c|c|}
\hline Area & Category & Rationale \\
\hline \multirow[t]{6}{*}{ Descriptive } & Authors & Name of author(s) \\
\hline & Title & Complete title of the paper \\
\hline & Year & Year of publication \\
\hline & Journal & $\begin{array}{l}\text { Journal in which it was published, book section or conference } \\
\text { proceedings, etc. }\end{array}$ \\
\hline & Country & Country where the research was conducted \\
\hline & Place of publication & Country where the research was published \\
\hline \multirow[t]{3}{*}{ Methodology } & Method used & The method used to conduct the research. \\
\hline & Paper type & Analytical, empirical, or a literature review. \\
\hline & Paper format & Journal paper, Conference paper, etc. \\
\hline \multirow[t]{5}{*}{ Thematic } & Type of social media & The type of social media studied. \\
\hline & Theme & $\begin{array}{l}\text { The focus of the research (e.g. motivation, communication, } \\
\text { collaboration, etc.) }\end{array}$ \\
\hline & Level & The level of focus (e.g. organization, group, individual, etc.) \\
\hline & Findings & The main findings of the paper related to the topic of investigation. \\
\hline & Other & $\begin{array}{l}\text { Any other information presented in the study that is relevant to this } \\
\text { research. }\end{array}$ \\
\hline
\end{tabular}

After recording the data from the studies, quantitative and qualitative analyses were conducted. From these analyses, characteristics and findings were identified according to the objectives and research questions of this review.

\section{Findings and discussion}

From the SLR, 4235 studies were initially retrieved. The SLR was performed on the 8 March 2015, with the initial set of studies limited to papers being published at that time. As mentioned prior, the removal of unrelated studies resulted in the final retention of 106 studies, which constituted the final set of studies analyzed in this review. A complete reference list is available in Appendix A.

\section{Overview of studies}

Figure II shows the type of social media discussed in the studies identified in this review. It clearly shows that wikis are the most comprehensively researched type of social media, seconded by social networks. 
Additionally, as the popularity and importance of social media has increased, research has begun to focus on the general use and impact of social media.

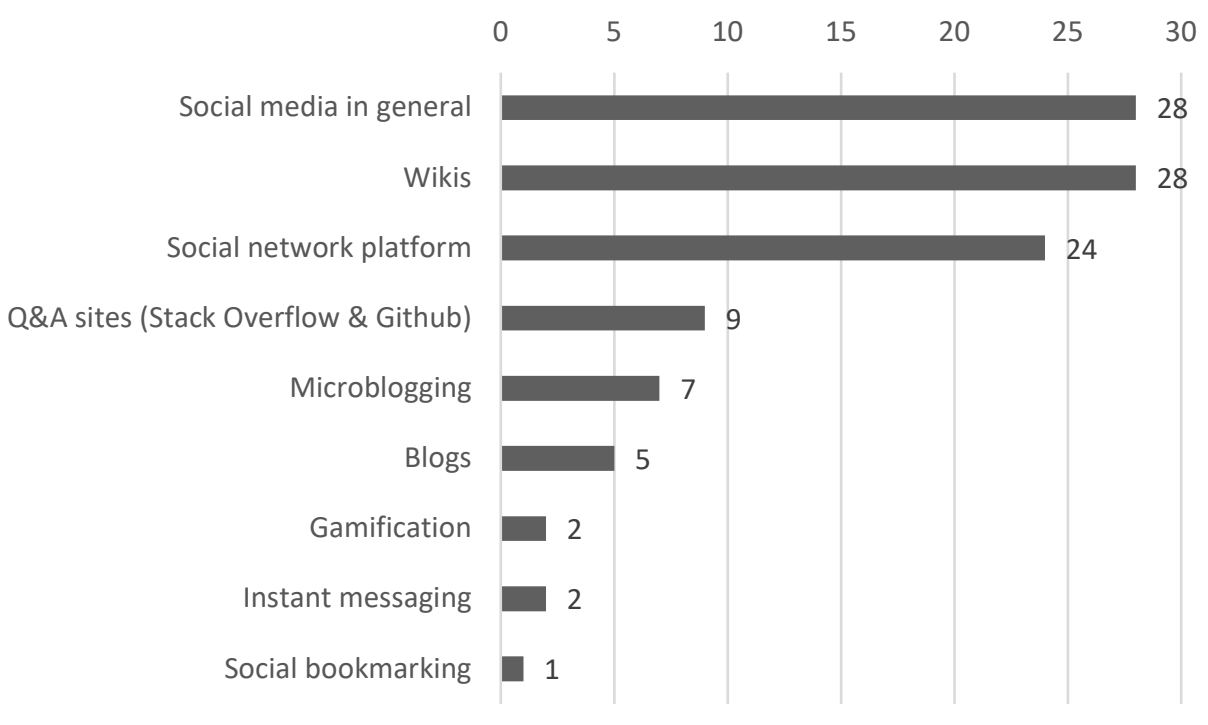

Figure II Number of studies for each type of social media

The results here are considerably different compared to Guiffrida and Dittrich (2013), who found that IMs were clearly the most studied social media tool. Their study addressed the general use of social media in global software development. IM is a tool to communicate short messages in a fast and simple manner, with the ability to reach out to others for quick answers to specific problems during a development activity. However, while IM is widespread within the field of software development, the fact that this specific type of social media is the focus of only two of the identified studies in this review shows that IM is not considered a viable tool for knowledge sharing.

The distribution of the final set of 106 studies is presented in Table $V$ by year. The findings illustrate the most comprehensively studied types of social media in relation to knowledge sharing. The table clearly indicates that research on knowledge sharing via wikis and social networks has been taking place for roughly a decade. Wikis have been the focus of many studies and research in this field, reaching a high in 2010 and 2011. Aside from a single exception, blogs and IMs were the focus of social media research in relation to knowledge sharing up to roughly 2010-11, following which there appears to have been a shift in focus. The findings of this review show that, after 2010-11, research on social media became more widespread and specific, likely due to the introduction of new tools and their increased popularity and usage. This also indicates a growing interest in social media for knowledge sharing and the acknowledgement of its potential benefits. 
Table V - Distribution of studies regarding each type of social media by year

\begin{tabular}{|c|c|c|c|c|c|c|c|c|c|c|c|}
\hline \multirow{2}{*}{ Social media } & \multicolumn{11}{|c|}{ Year } \\
\hline & 2005 & 2006 & 2007 & 2008 & 2009 & 2010 & 2011 & 2012 & 2013 & 2014 & 2015 \\
\hline Wikis & & 3 & 2 & 2 & 4 & 7 & 7 & 2 & 1 & & \\
\hline Social media in general & & & 1 & 3 & & 6 & 5 & 2 & 8 & 3 & \\
\hline Social network platform & 1 & 1 & 3 & 2 & 3 & 3 & 3 & 4 & 3 & & 1 \\
\hline $\begin{array}{l}\text { Q\&A sites (Stack Overflow \& } \\
\text { GitHub) }\end{array}$ & & & & & & & 2 & 2 & 3 & 2 & \\
\hline Microblogging & & & & & & & 1 & 1 & 3 & 2 & \\
\hline Blogs & & & & 1 & 1 & 2 & & & 1 & & \\
\hline Gamification & & & & & & & 1 & & & 1 & \\
\hline Instant messaging & & & & & & 1 & 1 & & & & \\
\hline Social bookmarking & & & & 1 & & & & & & & \\
\hline
\end{tabular}

The findings reveal that social media in general has received significant research attention since 2010. However, aside from wikis and social networks, there is a current lack of research on specific social media tools for knowledge sharing. We are currently witnessing a more widespread focus of research within the field, but there seems to be a demand for even further investigation of the potential of more specific social media tools.

In a big global study knowledge management (KM) experts stated that research in the relationship between $\mathrm{KM}$ and technological enablers often is retroactive and tries to make KM fit into a former defined theme (Sarka et al, 2014). This study seems to confirm this in relation to social media. That is, as social media becomes implemented in companies, researchers begin to change their focus toward these tools. Therefore, certain tools are only seriously researched after they become mainstream (Giuffrida \& Dittrich, 2013). The findings of this review show that researchers are only beginning to recognize the need to focus on newer aspects of social media and their specific functions, rather than offer comprehensive general discussions. Gamification, Q\&A sites, and microblogging, along with many other aspects of social media, have been part of the field's toolbox for many years now. Such features are already well implemented and used in the everyday life and the work processes of companies throughout the world. Despite this, however, research is only beginning to focus on these areas. Due to the rapid technological development within the field of social media, tools are constantly updated and quickly outdated, putting research in danger of being outdated even before it is published. 
It should be noted that this study's literature search was conducted in March of 2015, and therefore, not all papers published in 2015 were included in this review. Only a single paper from 2015 was found to be relevant to this review. However, under normal circumstances, the tendency shown in Table $V$ would most likely follow the same pattern for 2015.

\section{Research methods}

This review investigated how the different identified studies were conducted. The adopted research methods of these studies include a great mixture of quantitative and qualitative methods, as well as case studies. In addition, many studies have combined quantitative and qualitative methods to complement each other. This indicates a great mixture of research on knowledge sharing via social media, which ensures a more broad and accurate picture of the field (see Figure III). One particular method that appears to be overlooked in the studies is that of observations. While the many case studies all include activity logs and log content analysis, there is a lack of observational studies, which could provide new findings on the relationship between social media and knowledge sharing.

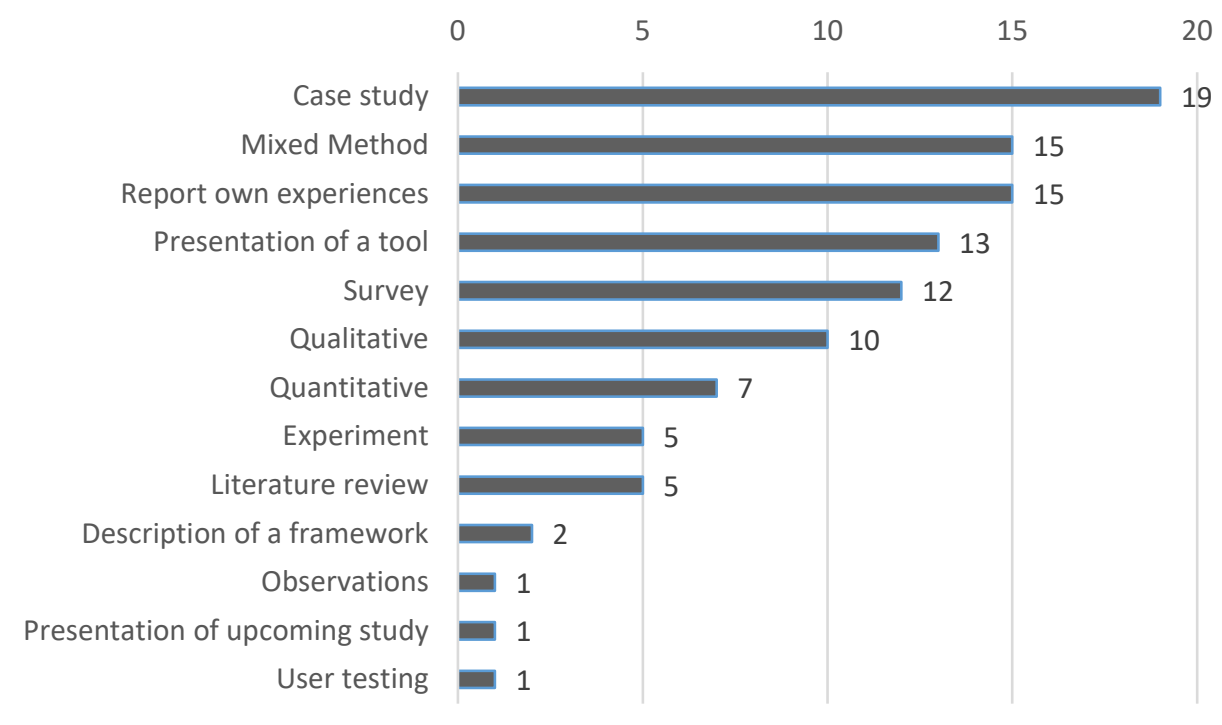

Figure III Research methods adopted

The vast majority of the identified studies in this review used an empirical approach (see Figure IV). Roughly a quarter of the studies were purely analytical, and only four literature reviews were identified. As mentioned prior, research within the field of social media for knowledge sharing is still developing, especially given more recent additions and developments. Therefore, there may not be a comprehensive body of data for conducting a literature review at this time, which is suggested by the fact that only four review were identified in this study. 


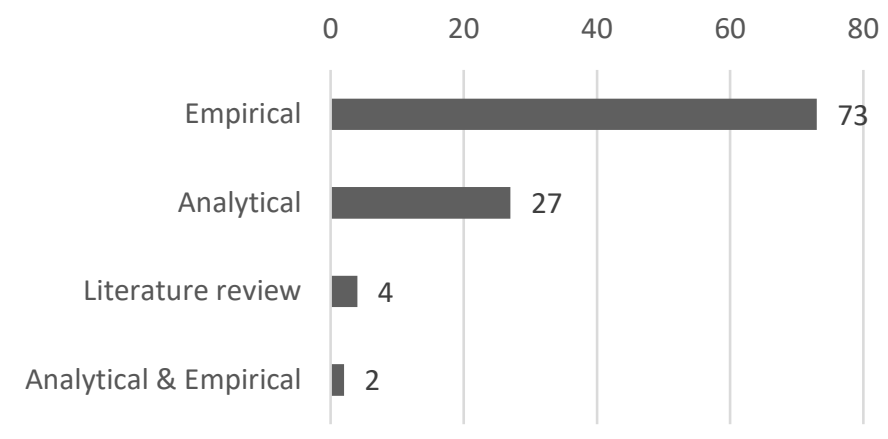

Figure IV - Distribution of paper types

\section{Type of research}

This review also investigated how research within social media for knowledge sharing is being presented. Figure $V$ shows that the preferred way to publish research within the field is via conference papers. Certain of these studies may have only qualified as conference papers, and thus were not developed further into journal papers. However, there might be another explanation as well. As mentioned prior, the technology within social media is rapidly changing and developing. In combination with a comprehensive and time consuming review process of journals this makes a very bad match. Therefore, sometimes it is preferred to use conferences to present ideas and research and it is not seen as worthwhile to go into the process of making a paper publishable for a giving journal. This is a challenge that needs to be dealt with within the research community. As social media research often focuses on the potential for fast and easy knowledge sharing, immediate collaboration across spatial and temporal boundaries, etc., perhaps some of these ideas and methods are suitable for advancing the publication process as well.

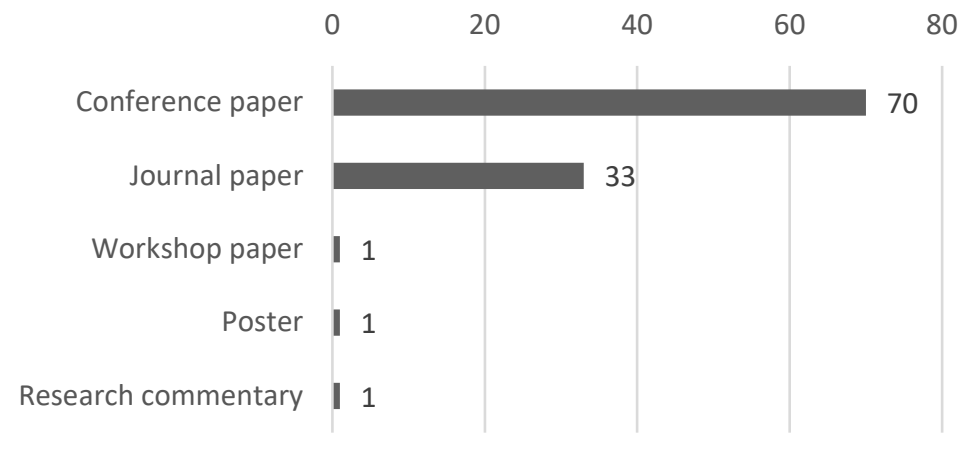

Figure V - Distribution of paper formats

\section{Usage of social media}

A large portion of the studies identified in this review deal with collaboration and communication, which is to be expected, as social media is generally regarded as a communication tool that enables collaboration. 
Moreover, a considerable amount of the studies place focus on KM activities and knowledge sharing. Together, these four categories account for more than $60 \%$ of the entire set of studies (see Figure VI). A great distribution is seen in the remaining themes, including motivation, general usage, and information sharing as the most represented. The diversity of themes helps to develop a more comprehensive understanding of the field. However, further studies are required on more minor topics, such as barriers, innovation, and success factors, to establish broad conclusions. As social media is known to be vital to socializing, it is surprising to find that only a few studies have investigated themes such as trust and socialization processes.

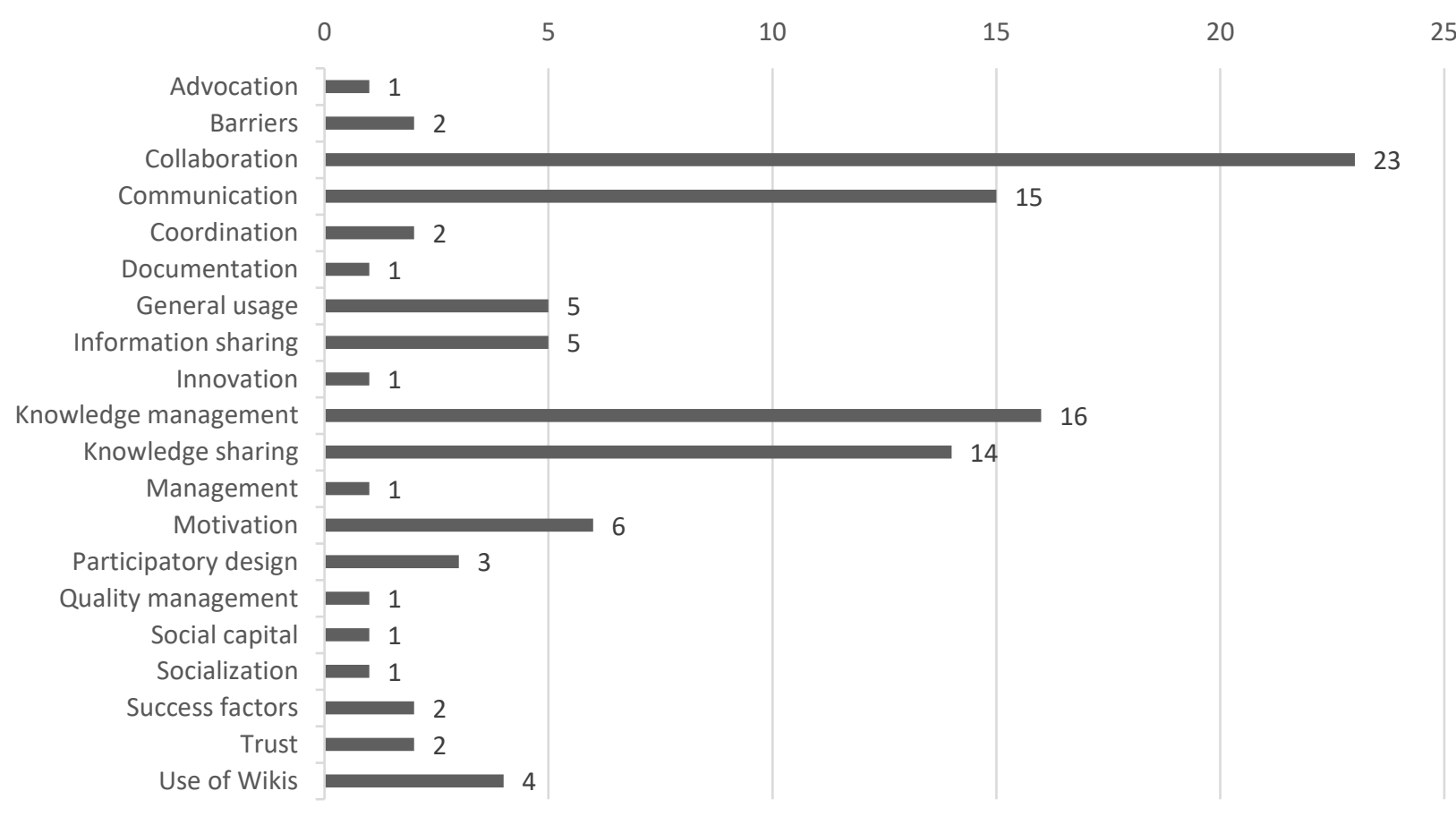

Figure $\mathrm{VI}$ - Themes

Another absent theme is implementation. Social media has been recognized for its communicative and collaborative potential and is expected to increasingly expand from the private sphere into companies. However, the question of how companies should prepare and act in order to ensure the successful implementation of social media is not present within the studies identified in this review.

\section{Research perspective}

An organizational focus is most commonly used in the selected studies. More than half of the entire set of studies investigate the impact, potential, etc., from an organizational perspective (see Figure VII). In these studies, the focus is, for example, on how organizational processes are affected by social media, or how social media can contribute to improve them. 


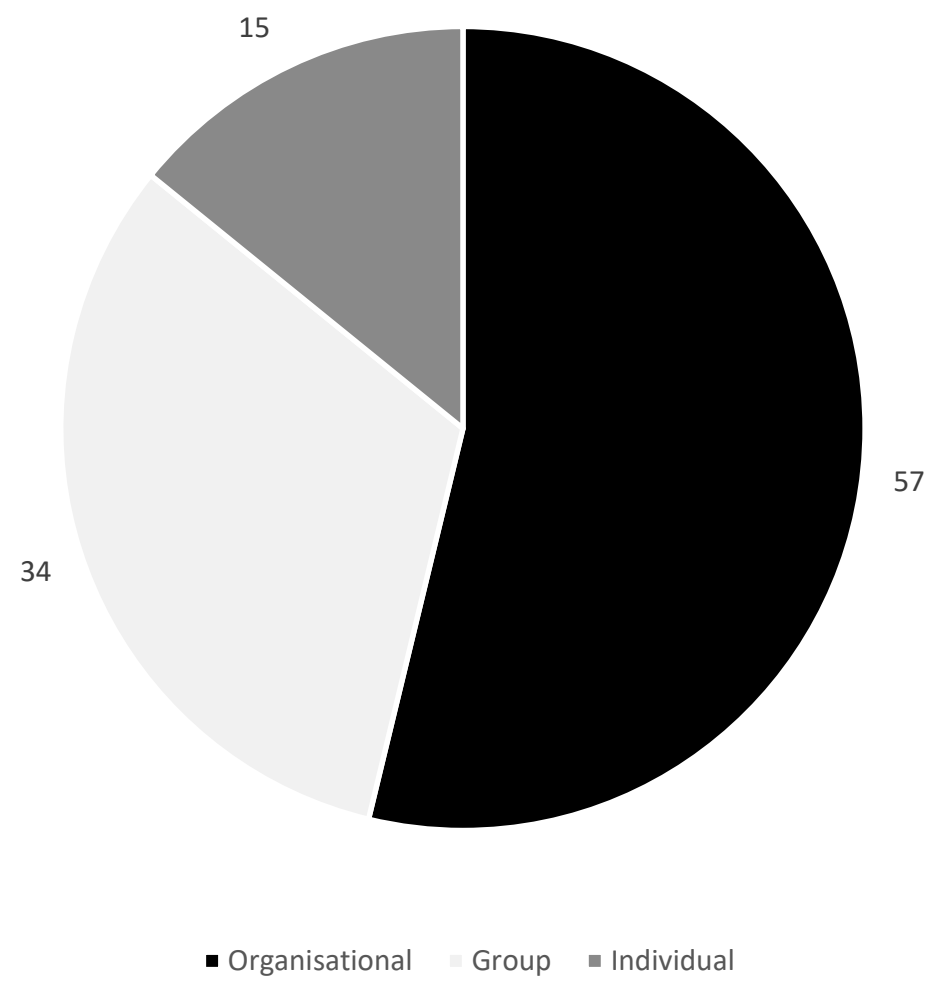

Figure VII - Research perspective

The main portion of the remaining studies focus from a group perspective on the processes, for example, within a single development team or department. Hence, these studies are more narrowly defined.

The last group of studies focus on the individual. However, these amount to as little as $14 \%$ of the entire set of studies. These studies focus on, for example, participation in online communities [CTA09], how usability information is shared [BHC08] and discussions on Q\&A sites [TBS11], [BYH14]. The majority of the studies in this group focus on how social media is used, and hence do not examine how social media affects the work processes of a single individual or their accompanying impacts. Very few studies touch upon factors such as motivation [HL07], [PTS13], [VSDF14], trust [AVHPM11], or work performance and value [CVGLG12]. This review reveals a tendency in research within knowledge sharing via social media toward investigating the subject from a general perspective, with a lack of focus on the impacts at the individual level. This conclusion is supported in [STDC10] where they proposed ten research questions that seek to understand the implications of social media related to software development. However, only one of these questions addresses impacts on an individual level (i.e. interruptions and information overload). 


\section{Future research}

In this section, gaps in the current published studies on knowledge sharing via social media are gathered to assist future research agendas.

More tool or function specific research:

Research on knowledge sharing via social media is characterized by a general approach. Therefore, additional studies on specific tools and processes will help to achieve a more comprehensive understanding of these different tools/functions and their related benefits and challenges.

More prospective research:

Research within this field is struggling to keep up with rapidly changing technological development, with findings potentially becoming outdated before being published. Thus, there is a need for more prospective research. Furthermore, changes may be necessary to the extensive process of submission to publications, such as increasing the speed of this process, or the establishment of completely other ways of publishing academic material. Perhaps certain aspects of social media could be used in this process.

Lack of observational studies:

Surprisingly few of the identified studies included observations of social media use for knowledge sharing. Many of the case studies use content log analysis or something similar, but it appears advisable to complement existing research by taking a step back and concentrate some additional efforts on understanding the scattered practices. However, this could interfere with the goal of being prospective. Therefore, there is also a need to use observations to create suggestions and/or understandings for future use of social media for knowledge sharing.

\section{Lack of implementation studies:}

As noted prior, implementation is not discussed in any of the identified papers in this review. Thus, more research on the successful introduction of social media for knowledge sharing in companies in needed to advance an understanding and knowledge of the field.

Lack of focus on the individual:

One of the major research gaps on knowledge sharing via social media identified in this review is a lack of focus on the individual. More than $85 \%$ of the studies focus at the organizational or group level. For a more comprehensive and adequate understanding and knowledge of the field, it is necessary to concentrate more research on the impact of social media use on the individual. 
Addressing the above stated areas will not only increase knowledge within the field, but also aid in enhancing the available support for both researchers and practitioners.

\section{Conclusion}

The systematic literature review (SLR) presented in this paper aimed at providing a comprehensive overview of studies focused on knowledge sharing via social media, as well as identifying gaps in the literature to assist future research agendas.

Social media is typically used for collaboration, KM, communication, and knowledge sharing. The majority of published papers within the field are empirically-based and in the format of conference papers. Wikis, social media in general, and social network portals are the most studied tools. Research addressing more specific and new types of social media for knowledge sharing will not only provide more information on the field, but will also increase support available for software developers who currently use or are considering using such tools.

Social media is constantly developing, and therefore research struggles to keep up with its progress. Thus, there is a need to be more prospective and to decrease the duration of the review processes. Furthermore, observational studies and research of implementation of social media will add to existing research and improve available knowledge in the field.

The individual is surprisingly absent in the identified studies of this review, which primarily focus on general impacts and benefits at the organizational level. Increased attention should therefore be given to the effects of knowledge sharing via social media at the individual level so as to gain a better and allencompassing understanding of how these technologies can be effectively utilized. 


\section{References}

Begel A, DeLine R \& Zimmermann T (2010) Social media for software engineering. In Proceedings of the FSE/SDP Workshop on the Future of Software Engineering Research, Santa Fe, New Mexico, USA.

Bell BS and Kozlowski SWJ (2002) A typology of virtual teams: Implications for effective leadership. Group \& Organizational Management, 27(1), 14-49.

Bertoni et al. (2012) The rise of social product development. International Journal of Networking and Virtual Organisations, 11(2), 188-207.

Black S, Harrison R and Baldwin M (2010) A survey of social media use in software systems development. Proceedings of the 1st Workshop on Web 2.0 for Software Engineering, p 1.

Cho YI (2008) Intercoder reliability. In Encyclopedia of Survey Research Methods (Lavrakas PJ, Ed), pp 344345, Sage Publications, Thousand Oaks, CA.

Cummings JN, Espinosa JA, and Pickering CK (2009) Crossing spatial and temporal boundaries in globally distributed projects: A relational model of coordination delay. Information Systems Research, 20(3), 420-439.

Deal JJ, Altman DG and Rogelberg SG (2010) Millennials at work: What we know and what we need to do (If anything). Journal of Business and Psychology, 25(2), 191-199.

Denyer D and Tranfield D (2009) Producing a systematic review. In The Sage Handbook of Organizational Research Methods (Buchanan DA and Bryman A (Ed), pp 671-689, Sage, London.

Denyer D, Tranfield D and van Aken JE (2008) Developing design propositions through research synthesis. Organization Studies, 29(3), 393-415.

Duff A (1996) The literature search: A library-based model for information skills instuction. Library Review, 45(4), 14-18.

Espinosa JA, Slaughter SA, Kraut RE and Herbsleb JD (2007) Team knowledge and coordination in geographically distributed software development. Journal of Management Information Systems, 24(1), 135-169.

Faraj S and Sproull L (2000) Coordinating expertise in software development teams. Management Science, 46(12), 1554-1568.

Farkas MG (2007) Social software in libraries: Building collaboration, communication, and community 
online. Information Today Inc.

Ferro T, Divine D and Zachry M (2012) Knowledge workers and their use of publicly available online services for day-to-day work. In Proceedings of the 30th ACM International Conference on Design of Communication, p 47, Association for Computing Machinery, Seattle.

Fisher K and Fisher MD (2001) The distance manager. A hands-on guide to managing off-site employees and virtual teams. McGraw-Hill.

Gancho S, Cooper R and Evans M (2013) The impact of design in social media today. In Proceedigns of the 2nd Cambridge Academic Design Management Conference.

Giuffrida R and Dittrich Y (2013) Empirical studies on the use of socail software in global software development - A systematic mapping study. Information and Software Technology, 55(7), 1143-1164.

Grabowski M and Roberts KH (2016) Reliability seeking virtual organizations: Challenges for high reliability organizations and resilience engineering. Safety Science.

Hansen MT, Nohria N and Tierney T (1999) What's your strategy for knowledge management. Harvard Business Review, 77(2), 106-116.

Heisig P (2009) Harmonisation of knowledge management - comparing $160 \mathrm{KM}$ frameworks around the globe. Journal of Knowledge Management, 13(4), 4-31.

Kaplan AM and Haenlein M (2010) Users of the world, unite! The challenges and opportunities of Social Media. Business Horizons, 53(1), 59-68.

Keitt T, Brown M and Dang J (2011) The state of collaboration software implementations. Forrester Research.

Kotlarsky J and Oshri I (2005) Social ties, knowledge sharing and successful collaboration in globally distributed system development projects. European Journal of Information Systems, 14(1), 37-48.

Kraut RE and Streeter LA (1995) Coordination in software development. Communications of the ACM, $38(3), 69-81$.

Larsson A (2005) Engineering know-who: Why social connectedness matters to global design teams. Luleå University of Technology, Luleå, Sweden.

Levy M (2009) Web 2.0 implications on knowledge management. Journal of Knowledge Management, $13(1), 120-134$. 
Mamykina L, Manoim B, Mittal M, Hripcsak G and Hartmann B (2011) Design Lessons from the fastest Q\&A site in the west. In Proceedings of the CHI 2011, ACM, May 7-12.

McAfee A (2010) A sea change? [WWW document] http://andrewmcafee.org/2010/11/mcafee-ciosenterprise2-mainstream/ (accessed 22 January 2015).

Miles MB and Huberman M (1994) Qualitative data analysis: A sourcebook of new methods, Sage Publications, Beverly Hills.

Perrin A (2015) Social media usage: 2005-2015. Pew Research Center.

Prensky M (2001) Digital natives, digital immigrants. On the Horizon, 9(5), 1-6.

Refworks (2015) Refworks, Your online research management, writing and collaboration tool. ProQuest, Bethesda, USA.

Richter D, Reimer K and vom Brocke J (2011) Internet social networking. Business and Information Systems Engineering, 3(2), 89-101.

Ryle G (1984) The concept of mind. University of Chicago Press, Chicago.

Sarka P, Caldwell NHM, Ipsen C, Maier AM and Heisig P (2014) Future research in technological enablers for knowledge management: A worldwide expert study. In Proceedings of the BAM 2014 Conference, Belfast, Northern Ireland.

Sarka P, Ipsen C, Heisig P and Maier AM (2014) Engineers are using social media for work purposes. In Proceedings of the 13th International Design Conference, p 589, Dubrovnik, Croatia.

Selwyn N (2009) The digital native - myth and reality. Aslib Proceedings, 61(4), 364-379.

Squire M (2015) "Should we move to Stack Overflow?" Measuring the utility of social media for developer support, In proceedings of the $37^{\text {th }}$ International Conference on Software Engineering, Florence, Italy, pp. 219-228.

Storey MA, Singer L, Cleary B, Filho FF and Zagalsky A (2014) The (R)evolution of social media in software engineering, In proceedings of Future of Software Engineering (FOSE), May 31-June 7, Hyderabad, India, pp. 100-116.

Storey MA, Treude C, van Deursen A and Cheng LT (2010) The impact of social media on software engineering practices and tools. In Proceedings of the FSE/SDP workshop on Future of software engineering research, p 359, ACM Press, New York, USA. 
Szulanski G (2000) The process of knowledge transfer: a diachronic analysis of stickness. Organizational Behavior and Human Decision Processes, 82(1), 9-27.

Treude C, Barzilay O and Storey MA (2011) How do programmers ask and answer questions on the web? (NIER track). In proceedings of the International Conference on Software Engineering (ICSE'11), ACM, May 21-28, Honolulu, USA, pp. 804-807. 


\section{Appendix A - Selected studies}

\begin{tabular}{|c|c|}
\hline [ACGL08] & $\begin{array}{l}\text { Abbattista F, Calefato F, Gendarmi D and Lanubile F (2008) Incorporating social software into distributed agile } \\
\text { development environments. In Proceedings of the 23RD IEEE/ACM International Conference on Automated } \\
\text { Software Engineering Workshops, pp 248-253, L'Aquila, Italy. }\end{array}$ \\
\hline$[\mathrm{AG} 12]$ & $\begin{array}{l}\text { Arazy } O \text { and Gellatly IR (2012) Corporate wikis: The effects of owners' motivation and behavior on group } \\
\text { members' engagement. Journal of Management Information Systems, 29(3), 87-116. }\end{array}$ \\
\hline [AM11] & Anderson S and Mohan K (2011) Social Networking in Knowledge Management. IT Professional, 13(4), 24-28. \\
\hline [ARACLD07] & $\begin{array}{l}\text { Araujo RM, Rezende EA, Andrade TS, Chaves VM, Lopes MG and Diirr B ( 2007) People in network, collaboration } \\
\text { for action new supporting requirements. In Proceedings of the } 2007 \text { 11th International Conference on } \\
\text { Computer Supported Cooperative Work in Design - CSCWD, pp 934-944, IEEE Conference Publications, } \\
\text { Melbourne, Australia. }\end{array}$ \\
\hline [AVHPM11] & $\begin{array}{l}\text { Aranda GN, Vizcaíno A, Hernández JL, Palacio RR and Morán AL (2011) Trusty: A tool to improve communication } \\
\text { and collaboration in DSD. In Proceedings of the 17th International Conference on Collaboration and Technology } \\
\text { - CRIWG, pp 224-231, Paraty, Brazil. }\end{array}$ \\
\hline$[\mathrm{BC} 11]$ & $\begin{array}{l}\text { Burger-Helmchen T and Cohendet P (2011) User communities and social software in the video game industry. } \\
\text { Long Range Planning, 44(5-6), 317-343. }\end{array}$ \\
\hline [BCFSS11] & $\begin{array}{l}\text { Burns MJ, Craig RB, Friedman BD, Schott PD and Senot C (2011) Transforming enterprise communications } \\
\text { through the blending of social networking and unified communications. Bell Labs Technical Journal, 16(1), 19- } \\
34 \text {. }\end{array}$ \\
\hline [BDZ10] & $\begin{array}{l}\text { Begel A, DeLine R and Zimmermann T (2010) Social media for software engineering. In Proceedings of the } \\
\text { FSE/SDP workshop on Future of software engineering research - FoSER, p 33, Santa Fe, NM, USA. }\end{array}$ \\
\hline [BH08] & $\begin{array}{l}\text { Benlian A and Hess T (2008) The adoption of and satisfaction with Web2.0 based collaboration and knowledge } \\
\text { management technologies in global software development - insights from an empirical study. In Proceedings of } \\
\text { the 19th Australasian Conference on Information Systems - ACIS, pp 107-115, Christchurch; New Zealand. }\end{array}$ \\
\hline$[\mathrm{BHCO8}]$ & $\begin{array}{l}\text { Bach PM, Hao J and Carroll JM (2008) Sharing usability information in interactive system development. In } \\
\text { Proceedings of the } 2008 \text { international workshop on Cooperative and human aspects of software engineering - } \\
\text { CHASE, pp 9-12, Leipzig, Germany. }\end{array}$ \\
\hline [BJ10] & $\begin{array}{l}\text { Black S and Jacobs J (2010) Using Web } 2.0 \text { to improve software quality. In Proceedings of the 1st Workshop on } \\
\text { Web } 2.0 \text { for Software Engineering - Web2SE, pp 6-11, Cape Town, South Africa. }\end{array}$ \\
\hline$[B L 11]$ & $\begin{array}{l}\text { Bajic D and Lyons K (2011) Leveraging social media to gather user feedback for software development. In } \\
\text { Proceeding of the } 2 \text { nd international workshop on Web } 2.0 \text { for software engineering - Web2SE, pp 1-6, Waikiki, } \\
\text { Honolulu, HI, USA. }\end{array}$ \\
\hline [BLFN10] & $\begin{array}{l}\text { Bittar TJ, Lobato LL, Fortes RPM and Neto DF (2010) Accessible organizational elements in wikis with model- } \\
\text { driven development. In Proceedings of the 28th ACM International Conference on Design of Communication - } \\
\text { SIGDOC, pp 49-56, Sao Carlos, Brazil. }\end{array}$ \\
\hline [BSSG11] & $\begin{array}{l}\text { Bougie G, Starke J, Storey MA and German DM (2011) Towards understanding twitter use in software } \\
\text { engineering: Preliminary findings, ongoing challenges and future questions. In Proceedings of the } 2 \text { nd } \\
\text { International Workshop on Web } 2.0 \text { for Software Engineering - Web2SE, pp 31-36, Waikiki, Honolulu, HI, USA. }\end{array}$ \\
\hline$[\mathrm{BTH} 14]$ & Barua A, Thomas SW and Hassan AE (2014) What are developers talking about? An analysis of topics and trends \\
\hline
\end{tabular}




\begin{tabular}{|c|c|}
\hline & Stack Overflow. Empirical Software Engineering, 19(3), 619-654. \\
\hline [CLS13] & $\begin{array}{l}\text { Calefato F, Lanubile F and Sportelli F (2013) Can social awareness foster trust building in global software teams? } \\
\text { In Proceedings of the } 2013 \text { International Workshop on Social Software Engineering - SSE, pp 13-16, Saint } \\
\text { Petersburg, Russian Federation. }\end{array}$ \\
\hline [CTA09] & $\begin{array}{l}\text { Cook E, Teasley SD and Ackerman MS (2009) Contribution, commercialization \& audience: Understanding } \\
\text { participation in an online creative community. In Proceedings of the ACM } 2009 \text { international conference on } \\
\text { Supporting group work - GROUP, pp 41-50, Sanibel Island, FL, United States. }\end{array}$ \\
\hline [CVGLG12] & $\begin{array}{l}\text { Cao X, Vogel DR, Guo X, Liu H and Gu J (2012) Understanding the Influence of social media in the workplace an } \\
\text { integration of media synchronicity and social capital theories. In Proceedings of the 45th Hawaii International } \\
\text { Conference on System Sciences, pp 3938-3947, Maui, HI. }\end{array}$ \\
\hline [DD14] & $\begin{array}{l}\text { Durao F and Dolog P (2014) Improving tag-based recommendation with the collaborative value of wiki pages for } \\
\text { knowledge sharing. Journal of Ambient Intelligence and Humanized Computing, 5(1), 21-38. }\end{array}$ \\
\hline [DG11] & $\begin{array}{l}\text { Dittrich Y and Giuffrida R (2011) Exploring the role of instant messaging in a global software development } \\
\text { project. In Proceedings of the IEEE Sixth International Conference on Global Software Engineering, pp 103-112, } \\
\text { Helsinki, Finland. }\end{array}$ \\
\hline [DGS10] & $\begin{array}{l}\text { Dullemond K, van Gameren B and van Solingen R (2010) Virtual open conversation spaces towards improved } \\
\text { awareness in a GSE setting. In Proceedigns of the 5th IEEE International Conference on Global Software } \\
\text { Engineering, pp 247-256, Princeton, NJ, United States. }\end{array}$ \\
\hline [DGSD13] & $\begin{array}{l}\text { Dullemond K, Van Gameren B, Storey MA and Van Deursen A (2013) Fixing the "out of sight out of mind" } \\
\text { problem: One year of mood-based microblogging in a distributed software team. In Proceedings of the IEEE } \\
\text { International Working Conference on Mining Software Repositories, pp 267-276, San Francisco, CA, United } \\
\text { States. }\end{array}$ \\
\hline [DHRHPBB12] & $\begin{array}{l}\text { Daim TU, Ha A, Reutiman S, Hughes B, Pathak U, Bynum W and Bhatla A (2012) Exploring the communication } \\
\text { breakdown in global virtual teams. International Journal of Project Management, 30(2), 199-212. }\end{array}$ \\
\hline [DMCZPG10] & $\begin{array}{l}\text { van Deursen A, Mesbah A, Cornelissen B, Zaidman A, Pinzger M and Guzzi A (2010) Adinda: A knowledgeable, } \\
\text { browser-based IDE. In Proceedings of the 32nd ACM/IEEE International Conference on Software Engineering - } \\
\text { ICSE '10, Vol. 2, p 203, ACM Press. }\end{array}$ \\
\hline [EGW15] & $\begin{array}{l}\text { Ellison NB, Gibbs JL and Weber MS (2015) The use of enterprise social network sites for knowledge sharing in } \\
\text { distributed organizations: The role of organizational affordances. American Behavioral Scientist, 59(1), 103-123. }\end{array}$ \\
\hline [EKLSWHE06] & $\begin{array}{l}\text { Erickson T, Kellogg WA, Laff M, Sussman J, Wolf TV, Halverson CA and Edwards D (2006) A persistent chat space } \\
\text { for work groups: The design, evaluation and deployment of loops. In Proceedings of the 6th ACM conference on } \\
\text { Designing Interactive systems - DIS, pp 331-340, Pennsylvania, USA. }\end{array}$ \\
\hline [F07] & Fontana J (2007) Social networks find corp. friends. Network World, 24(44), 22. \\
\hline [GASB11] & $\begin{array}{l}\text { Garcia J, Amescua A, Sanchez MI and Bermon L (2011) Design guidelines for software processes knowledge } \\
\text { repository development. Information and Software Technology, 53(8), 834-850. }\end{array}$ \\
\hline [GCGR08] & $\begin{array}{l}\text { Gomez-Berbis J, Colomo-Palacios R, Garcia-Crespo A and Ruiz-Mezcua B (2008) ProLink: a semantics-based } \\
\text { social network for software projects. International Journal of Information Technology \& Management, 7(4), } \\
\text { 392-404. }\end{array}$ \\
\hline [GD13] & $\begin{array}{l}\text { Giuffrida R and Dittrich Y (2013) Empirical studies on the use of social software in global software development } \\
\text { - A systematic mapping study. Information and Software Technology, 55(7), 1143-1164. }\end{array}$ \\
\hline
\end{tabular}




\begin{tabular}{|c|c|}
\hline [GD14] & $\begin{array}{l}\text { Giuffrida R and Dittrich Y (2014) How social software supports cooperative practices in a globally distributed } \\
\text { software project. In Proceedings of the 7th International Workshop on Cooperative and Human Aspects of } \\
\text { Software Engineering - CHASE 2014, pp 24-31, ACM Press. }\end{array}$ \\
\hline [GGGGLOP10] & $\begin{array}{l}\text { Garcia R, Gil R, Gimeno JM, Granollers T, Lopez JM, Oliva M and Pascual A (2010) Semantic wiki for quality } \\
\text { management in software development projects. IET Software, 4(6), 386-395. }\end{array}$ \\
\hline [GMH13] & $\begin{array}{l}\text { Gopsill JA, McAlpine HC and Hicks BJ (2013) A social media framework to support engineering design } \\
\text { communication. Advanced Engineering Informatics, 27(4), 580-597. }\end{array}$ \\
\hline [GP10] & $\begin{array}{l}\text { Grudin J and Poole ES (2010) Wikis at work: Success factors and challenges for sustainability of enterprise wikis. } \\
\text { In Proceedings of the 6th International Symposium on Wikis and Open Collaboration - WikiSym '10, p 1, ACM } \\
\text { Press. }\end{array}$ \\
\hline [GS07] & $\begin{array}{l}\text { Gupta A and Seshasai S (2007) 24-hour knowledge factory: Using internet technology to leverage spatial and } \\
\text { temporal separations. ACM Transactions on Internet Technology, 7(3), 14-22. }\end{array}$ \\
\hline [GT12] & $\begin{array}{l}\text { Gourova E and Toteva K (2012) Enhancing knowledge creation and innovation in SMEs. In Proceedigns of the } \\
\text { Mediterranean Conference on Embedded Computing - MECO 2012, 292-297, IEEE Conference Publications, } \\
\text { Bar, Montenegro. }\end{array}$ \\
\hline [GT13] & $\begin{array}{l}\text { Galster M and Tofan D (2013) Exploring possibilities to analyse microblogs for dependability information in } \\
\text { variability-intensive open source software systems. In Proceedings of the } 2013 \text { IEEE International Symposium on } \\
\text { Software Reliability Engineering Workshops - ISSREW 2013, pp 321-325. }\end{array}$ \\
\hline [GWLLDK11] & $\begin{array}{l}\text { Gurzick D, White KF, Lutters WG, Landry BM, Dombrowski C and Kim JY (2011) Designing the future of } \\
\text { collaborative workplace systems: Lessons learned from a comparison with alternate reality games. In } \\
\text { Proceedings of the } 2011 \text { iConference - iConference '11, pp 174-180, ACM Press. }\end{array}$ \\
\hline [H10] & $\begin{array}{l}\text { Hester AJ (2010) Increasing collaborative knowledge management in your organization: Characteristics of wiki } \\
\text { technology and wiki users. In Proceedings of the } 2010 \text { Special Interest Group on Management Information } \\
\text { System's 48th annual conference on Computer personnel research on Computer personnel research - Sigmis } \\
\text { CPR '10, pp } 158 \text { - 164, ACM Press. }\end{array}$ \\
\hline [HLLA12] & $\begin{array}{l}\text { Hoong ALS, Lim TM, Leow SK and Aun JLR (2012) A study on the use of "yams" for enterprise knowledge } \\
\text { sharing. In Proceedings of the 2nd International Conference on Digital Information and Communication } \\
\text { Technology and Its Applications - DICTAP 2012, pp 183-188. }\end{array}$ \\
\hline [HL07] & $\begin{array}{l}\text { Huffaker D and Lai J (2007) Motivating online expertise-sharing for informal learning: The influence of age and } \\
\text { tenure in knowledge organizations. In Proceedings of the 7th IEEE International Conference on Advanced } \\
\text { Learning Technologies - ICALT 2007, pp 595-599, IEEE Conference Publications. }\end{array}$ \\
\hline [HL14] & $\begin{array}{l}\text { Hoong ALS and Lim TM (2014) A case study on the use of enterprise microblogging to improve knowledge } \\
\text { sharing. In Proceedings of the } 2014 \text { IEEE International Conference on Progress in Informatics and Computing - } \\
\text { PIC 2014, pp 674-678, IEEE Conference Publications, KL, Malaysia. }\end{array}$ \\
\hline [HRPW13] & $\begin{array}{l}\text { Hess J, Randall D, Pipek V and Wulf V (2012) Involving users in the wild - Participatory product development in } \\
\text { and with online communities. International Journal of Human Computer Studies, 71(5), 570-589. }\end{array}$ \\
\hline [HZZO7] & $\begin{array}{l}\text { Hu C, Zhao Y and Zhao X (2007) Wiki-based knowledge sharing in a knowledge-intensive organization. } \\
\text { International Federation for Information Processing, 252, 18-25. }\end{array}$ \\
\hline [J11] & $\begin{array}{l}\text { Johri A (2011) Look ma, no email! Blogs and IRC as primary and preferred communication tools in a distributed } \\
\text { firm. In Proceedings of the ACM } 2011 \text { conference on Computer supported cooperative work - CSCW '11, p 305, }\end{array}$ \\
\hline
\end{tabular}




\begin{tabular}{|c|c|}
\hline & ACM Press. \\
\hline [JM10] & $\begin{array}{l}\text { Jarvenpaa SL and Majchrzak A (2010) Vigilant Interaction in knowledge collaboration: Challenges of online user } \\
\text { participation under ambivalence. Information Systems Research, 21(4), 773-784. }\end{array}$ \\
\hline [JP013] & $\begin{array}{l}\text { Juárez-Ramírez R, Pimienta-Romo R and Ocegueda-Miramontes V (2013) Supporting the Software development } \\
\text { process using social media experiences with student projects. In Proceedings of the } 2013 \text { IEEE 37th Annual } \\
\text { Computer Software and Applications Conference Workshops, pp 656-661. }\end{array}$ \\
\hline [КАВ09] & $\begin{array}{l}\text { Kleiner F, Abecker A and Brinkmann SF (2009) WiSyMon: Managing systems monitoring information in semantic } \\
\text { wikis. In Proceedings of the 5th International Symposium on Wikis and Open Collaboration - WikiSym '09, p 1, } \\
\text { ACM Press. }\end{array}$ \\
\hline [KKMR09] & $\begin{array}{l}\text { Kaiser S, Kansy S, Mueller-Seitz G and Ringlstetter M (2009) Weblogs for organizational knowledge sharing and } \\
\text { creation: a comparative case study. Knowledge Management Research \& Practice, 7(2), 120-130. }\end{array}$ \\
\hline [KM08] & $\begin{array}{l}\text { Kaiser S and Mueller-Seitz G (2008) Leveraging lead user knowledge in software development - The case of } \\
\text { weblog technology. Industry and Innovation, 15(2), 199-221. }\end{array}$ \\
\hline [KPVKMMNP13] & $\begin{array}{l}\text { Kopecký M, Pokorný J, Vojtás P, Kubalík J, Matousek K, Maryska M, Novotný O and Peska L (2013) Testing and } \\
\text { evaluating software in a social network creating baseline knowledge. Frontiers in Artificial Intelligence and } \\
\text { Applications, 251, 127-141. }\end{array}$ \\
\hline [KS06] & $\begin{array}{l}\text { Korthaus } \mathrm{A} \text { and Schader } \mathrm{M} \text { (2006) Using a yopic grid and semantic wikis for ontology-based distributed } \\
\text { knowledge management in enterprise software development processes, In Proceedings of the } 10^{\text {th }} \text { IEEE } \\
\text { International Enterprise Distributed Object Computing Conference Workshops - EDOCW'06, p 4, IEEE } \\
\text { Conference Publications. }\end{array}$ \\
\hline [KS13] & $\begin{array}{l}\text { Kügler M and Smolnik S (2013) Just for the fun of it? Towards a model for assessing the individual benefits of } \\
\text { employees' enterprise social software usage. In Proceedings of the 46th Hawaii International Conference on } \\
\text { System Sciences, pp 3614-3623. }\end{array}$ \\
\hline [KYO10] & $\begin{array}{l}\text { Kanbe M, Yamamoto S and Ohta T (2010) A proposal of TIE model for communication in software development } \\
\text { process. Lecture Notes in Artificial Intelligence, } 6284,104-115 .\end{array}$ \\
\hline [L06] & Louridas P (2006) Using wikis in software development. IEEE Software, 23(2), 88-91. \\
\hline [LAC09] & $\begin{array}{l}\text { Li J, Ayala C and Conradi R (2009) Role-based wiki for reuse of off-the-shelf components. In Proceedings of the } \\
\text { ICSE Workshop on Wikis for Software Engineering - Wikis4SE 2009, pp 78-81. }\end{array}$ \\
\hline [LCZF12] & $\begin{array}{l}\text { Li M, Chen G, Zhang Z and Fu Y (2012) A social collaboration platform for enterprise social networking. In } \\
\text { Proceedings of the IEEE 16th International Conference on Computer Supported Cooperative Work in Design - } \\
\text { CSCWD 2012, pp 671-677. }\end{array}$ \\
\hline [LDPLV11] & $\begin{array}{l}\text { Lykourentzou I, Dagka F, Papadaki K, Lepouras G and Vassilakis C (2012) Wikis in enterprise settings: A survey. } \\
\text { Enterprise Information Systems, 6(1), 1-53. }\end{array}$ \\
\hline [LHML08] & $\begin{array}{l}\text { Leshed G, Haber EM, Matthews T and Lau T (2008) CoScripter: Automating \& sharing how-to knowledge in the } \\
\text { enterprise. In Proceedings of the 26th Annual Chi Conference on Human Factors in Computing Systems Vols } 1 \\
\text { and 2, pp } 1719-1728 .\end{array}$ \\
\hline [LL11] & $\begin{array}{l}\text { Lee ASH and Lim TM (2011) Enhance task-technology fit model by task categorization characteristics for a } \\
\text { proposed knowledge creation and sharing model via weblogs. In Proceedings of the } 7^{\text {th }} \text { International } \\
\text { Conference on Information technology in ASIA - CITA 11. P 1-6, IEEE Conference Publications. }\end{array}$ \\
\hline [LS10] & Lee SB and Shiva SG (2010) An approach to overcoming knowledge sharing challenges in a corporate IT \\
\hline
\end{tabular}




\begin{tabular}{|c|c|}
\hline & $\begin{array}{l}\text { environment. In Proceedings of the 5th International Conference on Global Software Engineering - ICGSE 2010, } \\
\text { pp 342-346. }\end{array}$ \\
\hline [MCRM14] & $\begin{array}{l}\text { Menolli A, Cunha MA, Reinehr S and Malucelli A (2015) "Old" theories, "new" technologies: Understanding } \\
\text { knowledge sharing and learning in Brazilian software development companies. Information and Software } \\
\text { Technology, 58, 289-303. }\end{array}$ \\
\hline [MH08] & $\begin{array}{l}\text { Maalej W and Happel HJ (2008) A lightweight approach for knowledge sharing in distributed software teams. } \\
\text { Lecture Notes in Artificial Intelligence, } 5345,14-25 \text {. }\end{array}$ \\
\hline [MMMHH11] & $\begin{array}{l}\text { Mamykina L, Manoim B, Mittal M, Hripcsak G and Hartmann B (2011) Design lessons from the fastest Q\&A site } \\
\text { in the west. In Proceedings of the } 2011 \text { annual conference on Human factors in computing systems - CHI ' } 11, p \\
2857, \text { ACM Press. }\end{array}$ \\
\hline [MTBC10] & $\begin{array}{l}\text { Martinez-Torres MR, Toral SL, Barrero F and Cortes F (2010) The role of internet in the development of future } \\
\text { software projects. Internet Research, 20(1), 72-86. }\end{array}$ \\
\hline [MWY06] & $\begin{array}{l}\text { Majchrzak A, Wagner C and Yates D (2006) Corporate wiki users: Results of a survey. In Proceedings of the } 2006 \\
\text { international symposium on Wikis - WikiSym '06, p 99, ACM Press.. }\end{array}$ \\
\hline [MWY13] & $\begin{array}{l}\text { Majchrzak A Wagner C and Yates D (2013) The impact of shaping on knowledge reuse for organizational } \\
\text { improvement with wikis. MIS Quarterly: Management Information Systems, 37(2), 455-469. }\end{array}$ \\
\hline [NIS11] & $\begin{array}{l}\text { Nath AK, Iyer LS and Singh R (2011) Uses of web } 2.0 \text { for knowledge management in organziations: Mutiple case } \\
\text { studies. In Proceedigns of the 17th Americas Conference on Information Systems } 2011 \text { - AMCIS 2011, pp 3494- } \\
3506 \text {. }\end{array}$ \\
\hline [OOKOM05] & $\begin{array}{l}\text { Ohira M, Ohoka T, Kakimoto T, Ohsugi N and Matsumoto } \mathrm{K}(2005) \text { Supporting knowledge collaboration using } \\
\text { social networks in a large-scale online community of software development projects. In Proceedings of the 12th } \\
\text { Asia-pacific Software Engineering Conference, } \mathrm{pp} 835-840 \text {. }\end{array}$ \\
\hline [P09] & $\begin{array}{l}\text { Phuwanartnurak AJ (2009) Did you put it on the wiki? Information sharing through wikis in interdisciplinary } \\
\text { design collaboration. In Proceedings of the } 27 \text { th ACM international conference on Design of communication - } \\
\text { SIGDOC'09, p 273, ACM Press. }\end{array}$ \\
\hline [PBL13] & $\begin{array}{l}\text { Ponzanelli L, Bacchelli A and Lanza M (2013) Leveraging crowd knowledge for software comprehension and } \\
\text { development. In Proceedings of the 17th European Conference on Software Maintenance and Reengineering, } \\
\text { pp 57-66. }\end{array}$ \\
\hline [PM08] & $\begin{array}{l}\text { Pan YX and Millen DR (2008) Information sharing and patterns of social interaction in an enterprise social } \\
\text { bookmarking service. In Proceedings of the 41st Annual Hawaii International Conference on System Sciences - } \\
\text { HICSS } 2008, p 158 .\end{array}$ \\
\hline [PP13] & $\begin{array}{l}\text { Pirkkalainen H and Pawlowski JM (2014) Global social knowledge management - Understanding barriers for } \\
\text { global workers utilizing social software. Computers in Human Behavior, 30, 637-647. }\end{array}$ \\
\hline [PTS13] & $\begin{array}{l}\text { Parnin C, Treude C and Storey MA (2013) Blogging developer knowledge: Motivations, challenges, and future } \\
\text { directions. In Proceedings of the 21ST IEEE International Conference on Program Comprehension - ICPC, pp } \\
211-214 .\end{array}$ \\
\hline [RB10] & $\begin{array}{l}\text { Rech J and Bogner C (2010) Qualitative analysis of semantically enabled knowledge management systems in } \\
\text { agile software engineering. International Journal of Knowledge Management, 6(2), 66-85. }\end{array}$ \\
\hline [RBH07] & $\begin{array}{l}\text { Rech J, Bogner C and Haas V (2007) Using wikis to tackle reuse in software projects. IEEE Software, 24(6), 99- } \\
104 .\end{array}$ \\
\hline
\end{tabular}




\begin{tabular}{|c|c|}
\hline [SAC10] & $\begin{array}{l}\text { de Sousa F, Aparicio M and Costa CJ (2010) Organizational wiki as a knowledge management tool. In } \\
\text { Proceedings of the 28th ACM International Conference on Design of Communication-SIGDOC, pp 33-39. }\end{array}$ \\
\hline [SCB12] & $\begin{array}{l}\text { Sillaber C, Chimiak-Opoka J and Breu R (2012) Supporting social driven requirements engineering processes } \\
\text { through knowledge sharing platforms. In Proceedings of IASTED International Conference on Software } \\
\text { Engineering-SE 2012, pp 60-66. }\end{array}$ \\
\hline [SDEL09] & $\begin{array}{l}\text { Steinfield C, DiMicco JM, Ellison NB and Lampe C (2009) Bowling online: Social networking and social capital } \\
\text { within the Organization. In Proceedings of the fourth international conference on Communities and } \\
\text { technologies-C\&T'09, p245-254, University Park, Pennsylvania, USA. }\end{array}$ \\
\hline [SDPH10] & $\begin{array}{l}\text { Seichter D, Dhungana D, Pleuss A and Hauptmann B (2010) Knowledge management in software ecosystems: } \\
\text { Software artefacts as first-class citizens. In Proceedings of the Fourth European Conference on Software } \\
\text { Architecture Companion Volume - ECSA '10. p 119, ACM Press. }\end{array}$ \\
\hline [SK09] & $\begin{array}{l}\text { Simha A and Kishore R (2009) Enhancing e-collaboration effectiveness through the use of wikis: A theoretical } \\
\text { examination in the context of requirements elicitation. International Journal of E-Collaboration, 5(3), 58-78. }\end{array}$ \\
\hline [SK11] & Standing C and Kiniti S (2011) How can organizations use wikis for innovation? Technovation, 31(7), 287-295. \\
\hline [SN13a] & $\begin{array}{l}\text { Samoilenko N and Nahar N (2013) IT tools for knowledge storage and retrieval in globally distributed complex } \\
\text { software and systems development of high-tech organizations. In Proceedings of PICMET 2013: Technology } \\
\text { Management in the IT-Driven Services, pp 1353-1369. }\end{array}$ \\
\hline [SN13b] & $\begin{array}{l}\text { Samoilenko N and Nahar N (2013) Knowledge sharing and application in complex software and systems } \\
\text { development in globally distributed high-tech organizations using suitable IT tools. In Proceedings of PICMET } \\
\text { 2013: Technology Management for Emerging Technologies, pp 1280-1294. }\end{array}$ \\
\hline [SP14] & $\begin{array}{l}\text { Sukale R and Pfaff MS (2014) QuoDocs: Improving developer engagement in software documentation through } \\
\text { gamification. In Proceedings of the extended abstracts of the } 32 \text { nd annual ACM conference on Human factors in } \\
\text { computing systems - CHI EA '14, pp 1531-1536, ACM Press. }\end{array}$ \\
\hline [SPCADFP12] & $\begin{array}{l}\text { de Souza CRB, Pinhanez CS, Cavalcante VF, Aluani F, Daros V, Ferreira D and de Paula R (2012) Designing an } \\
\text { enterprise social tool for cross-boundary communication, coordination, and information sharing. In Proceedings } \\
\text { of the 30th ACM international conference on Design of communication - SIGDOC, pp 55-63, Seattle, WA, United } \\
\text { States. }\end{array}$ \\
\hline [SS13] & $\begin{array}{l}\text { Singh P and Shadbolt N (2013) Linked data in crowdsourcing purposive social network. In Proceedings of the } \\
\text { 22nd International Conference on World Wide Web - WWW'13 Companion, pp 913-918, ACM Press. }\end{array}$ \\
\hline [SSCFZ14] & $\begin{array}{l}\text { Storey MA, Singer L, Cleary B, Figueira Filho F and Zagalsky A (2014) The (R) Evolution of social media in } \\
\text { software engineering. In Proceedings of the on Future of Software Engineering - FOSE 2014, pp 100-116, ACM } \\
\text { Press. }\end{array}$ \\
\hline [SSP08] & $\begin{array}{l}\text { Sarkar S, Sindhgatta R and Pooloth K (2008) A collaborative platform for application knowledge management in } \\
\text { software maintenance projects. In Proceedings of the 1st Bangalore annual Compute conference - Compute '08, } \\
\text { p 1, ACM Press. }\end{array}$ \\
\hline [STDC10] & $\begin{array}{l}\text { Storey MA, Treude C and van Deursen A (2010) The impact of social media on software engineering practices } \\
\text { and tools. In Proceedings of the FSE/SDP Workshop on Future of Software Engineering Research, 359-364. }\end{array}$ \\
\hline [STN09] & $\begin{array}{l}\text { Singh V, Twidale MB and Nichols DM (2009) Users of open source software - How do they get help. In } \\
\text { Proceedings of the } 42 \text { nd Hawaii International Conference on System Sciences, pp 1-10. }\end{array}$ \\
\hline [TBS11] & Treude C, Barzilay O and Storey MA (2011) How do programmers ask and answer questions on the web? (NIER \\
\hline
\end{tabular}




\begin{tabular}{|c|c|}
\hline & track). In Proceedings of the 33rd International Conference on Software Engineering - ICSE 2011, pp 804-807). \\
\hline [TBV11] & $\begin{array}{l}\text { Tang A, de Boer T and van Vliet H (2011) Building roadmaps: A knowledge sharing perspective. In Proceedings } \\
\text { of the 6th international workshop on SHAring and Reusing architectural Knowledge - SHARK '11, p 13, ACM } \\
\text { Press. }\end{array}$ \\
\hline [TDH12] & $\begin{array}{l}\text { Tsay JT, Dabbish L and Herbsleb J (2012) Social media and success in open source projects. In Proceedings of the } \\
\text { ACM } 2012 \text { conference on Computer Supported Cooperative Work Companion - CSCW '12, p 223, ACM Press. }\end{array}$ \\
\hline [TDH13] & $\begin{array}{l}\text { Tsay J, Dabbish L and Herbsleb JD (2013) Social media in transparent work environments. In Proceedings of the } \\
\text { 6th International Workshop on Cooperative and Human Aspects of Software Engineering - Chase 2013, pp 65- } \\
72 .\end{array}$ \\
\hline [TH11] & $\begin{array}{l}\text { Tseng SM and Huang JS (2011) The correlation between Wikipedia and knowledge sharing on job performance. } \\
\text { Expert Systems with Applications, 38(5), 6118-6124. }\end{array}$ \\
\hline [TS11] & $\begin{array}{l}\text { Treude C and Storey MA (2011) Effective communication of software development knowledge through } \\
\text { community portals. In Proceedings of the 19th ACM SIGSOFT Symposium on Foundations of Software } \\
\text { Engineering - SIGSOFT/FSE'11, pp 91-101. }\end{array}$ \\
\hline [V14] & $\begin{array}{l}\text { Vasilescu B (2014) Human aspects, gamification, and social media in collaborative software engineering. In } \\
\text { Companion Proceedings of the 36th International Conference on Software Engineering - ICSE Companion 2014, } \\
\text { pp 646-649, ACM Press. }\end{array}$ \\
\hline [VFS13] & $\begin{array}{l}\text { Vasilescu B, Filkov V and Serebrenik A (2013) StackOverflow and GitHub: Associations between software } \\
\text { development and crowdsourced knowledge. In Proceedings of the } 2013 \text { ASE/IEEE International Conference on } \\
\text { Social Computing - SOCIALCOM, pp 188-195. }\end{array}$ \\
\hline [VSDF14] & $\begin{array}{l}\text { Vasilescu B, Serebrenik A, Devanbu P and Filkov V (2014) How social Q\&A sites are changing knowledge sharing } \\
\text { in open source software communities. In Proceedings of the 17th ACM conference on Computer supported } \\
\text { cooperative work \& social computing - CSCW '14, pp 342-354, ACM Press. }\end{array}$ \\
\hline [WKSAF14] & $\begin{array}{l}\text { Wang X, Kuzmickaja I, Stol KJ, Abrahamsson P and Fitzgerald B (2014) Microblogging in open source software } \\
\text { development: The case of Drupal and Twitter. IEEE Software, 31(4), 72-80. }\end{array}$ \\
\hline [WW11] & $\begin{array}{l}\text { Wang WT and Wei ZH(2011) Knowledge sharing in wiki communities: an empirical study. Online Information } \\
\text { Review, 35(5), 799-820. }\end{array}$ \\
\hline [YHR13] & $\begin{array}{l}\text { Yang X, Hu D and Robert DM (2013) How microblogging networks affect project success of open source } \\
\text { software development. In Proceedings of the 46th Hawaii International Conference on System Sciences - HICSS } \\
2013, \mathrm{pp} 3178-3186 \text {. }\end{array}$ \\
\hline [ZKTM10] & $\begin{array}{l}\text { Zhang S, Köbler F, Tremaine } M \text { and Milewski AE (2010) Instant messaging in global software teams. } \\
\text { International Journal of E-Collaboration, 6(3), 43-63. }\end{array}$ \\
\hline [ZS11] & $\begin{array}{l}\text { Zeiller M and Schauer B (2011) Adoption, motivation and success factors of social media for team collaboration } \\
\text { in SMEs. In Proceedings of the 11th International Conference on Knowledge Management and Knowledge } \\
\text { Technologies - i-KNOW '11, p 1, ACM Press. }\end{array}$ \\
\hline [ZVB11] & $\begin{array}{l}\text { Zhu L, Vaghi I and Barricelli BR (2011) A meta-reflective wiki for collaborative design. In Proceedings of the 7th } \\
\text { International Symposium on Wikis and Open Collaboration - WikiSym '11, p 53, ACM Press. }\end{array}$ \\
\hline
\end{tabular}

